\title{
The origin, development, and future of the lithium-ion battery
}

\author{
Keith J. Stevenson
}

Published online: 3 May 2012

(C) Springer-Verlag 2012

On 22 October 2011, The Center for Electrochemistry at the University of Texas at Austin hosted a special symposium on "The Origin, Development, and Future of the Lithium-ion Battery." The symposium brought together experts and some of the original pioneers in the field from around the world to provide an opportunity to learn lessons from the development of the lithium-ion battery that can be applied to today's research. The presentations featured some historical perspective as well as new work and stimulated discussion on the possibilities and directions for future research in the field. A casual atmosphere fostered interaction between students, postdoctoral researchers, academic faculty, industry, and national labs.

The symposium was an event of the International Year of Chemistry (2011), a celebration of the achievements of chemistry and its contributions to the wellbeing of humankind. Over 30 years have passed since John Goodenough reported the invention of $\mathrm{LiCoO}_{2}$ as a positive electrode material in 1980. Also in that year, Rachid Yazami demonstrated the reversible electrochemical intercalation of lithium into graphite, which he reported in 1981 and 1982. Akira Yoshino commissioned the fabrication of a batch of prototype lithiumion cells in 1986, and Sony began mass producing lithium-ion batteries in 1991. The lithium-ion battery

K. J. Stevenson $(\bowtie)$

Department of Chemistry \& Biochemistry,

University of Texas at Austin,

1 University Station A5300,

Austin, TX 78712-1065, USA

e-mail: stevenson@cm.utexas.edu
(LIB) has been firmly established in a wide range of electronic applications, and LIB production now amounts to some US\$1.0 billion. Today, we are at the beginning of full-scale adoption of the LIB in electric vehicles and hybrid electric vehicles. The evolution of the LIB continues apace, with issues such as safety, higher capacity, cost reduction, and mass production each a focus of intensive research throughout the world. The development of new battery systems based on the LIB will spur another leap in innovation.

The symposium featured opening remarks from Allen J. Bard, Director of the Center for Electrochemistry, then presentations from John Goodenough (The University of Texas at Austin), Claude Delmas (CNRS, Université de Bordeaux, ICMCB), Michael Thackeray (Argonne National Laboratory), Rachid Yazami (Nanyang Technological University), Arumugam Manthiram (The University of Texas at Austin), Akira Yoshino (Asahi Kasei Corporation), Karim Zaghib (Institut de Recherche d'Hydro-Quebec), and Masataka Wakihara (Tokyo Institute of Technology).

Here, we have collected some of the papers that were presented at the symposium. Masataka Wakihara and coworkers discuss a new all-solid polymer electrolyte with improved ionic conductivity over $\mathrm{PEO}^{1}$. Karim Zaghib and coworkers present a review on the progress on the physical chemistry of the olivine compounds ${ }^{2}$. They focus on the development of understanding of $\mathrm{LiFePO}_{4}$ cathodes through to their widespread use in

\footnotetext{
${ }^{1}$ Published in: J Solid State Electrochem (2012) 16:847-855

${ }^{2}$ Published in: J Solid State Electrochem (2012) 16:835-845
} 
new generation Li-ion batteries and discuss pathways to increase the performance of Li-ion batteries with the other olivines. Finally, LIB pioneer John Goodenough gives his thoughts on "Rechargeable Batteries: Challenges Old and New," including discussion of cost, safety, energy, density, life, and rate. Addressing the challenge of today's energy storage needs for electrical power grid and automotive applications, he presents ideas on how to increase the cell capacity beyond what is possible with an insertion compound cathode. 